\title{
China's Rural Accountants Existing Problems and Cause Analysis
}

\author{
Di Qin * \\ School of Economics. Beijing Technology and Business \\ University \\ BTBU \\ Bei Jing, China \\ e-mail: qdcbtx@163.com \\ * Corresponding Author
}

\author{
Shibo Xin \\ School of Economics. Beijing Technology and Business \\ University \\ BTBU \\ Bei Jing, China \\ e-mail: xsblm@163.com
}

\begin{abstract}
China's rural accounting appears new circumstances and problems with the development of social economy and diversification of interest distribution. This paper is intended to analysis the problems existed in China rural accountants. There are research results and China's rural accounting information in 2014 to be referenced. An analysis of rural financial status quo is presented. It is pointed that the deficiency of professional knowledge and supervision, the lack of professional ethics as well as work enthusiasm and low work efficiency contribute to these problems. Based on the cause of problems, this paper outlines some strategies.
\end{abstract}

Keywords-countryside; financial management; rural accountants; existent problems; suggestions

\section{INTRODUCTION}

Since the 21st century, rural people's livelihood has been improved and society has been harmonious. Positive social background makes a contribution to construct new countryside. Rural financial staffs are one of the most important undertakers of financial management work. The level of rural accountants is closely linked to the order and effect of rural financial management. Achievements of new socialist countryside construction will be discounted if the problems in rural accountants are not solved. To promote rural economic development, we should realize the importance and urgency of rural financial management and solve these problems. This article study the problems in rural accountants based on the background and existing literature.

\section{RESEARCH ACTUALITY OF CHINA'S FINANCIAL PROBLEMS}

Rural finance is a basic and fundamental problem in relation to agricultural harvest and rural prosperity. Rural accounting is a hot topic in recent years. Scholars have studied the rural financial system from different angles including accounting informationzation, professional ethics of rural accountants and disclosure system of finance in rural areas and so on.

\section{A. Accounting Informationization In Rural Areas}

Wang Jiancheng[1] introduced the basic theory of accounting computerization. Liu Zhilin[2] put forward that the rural accounting informationzation must consider the rural thought tradition, the new rural financial policy and current financial management system. $\mathrm{Xu}$
Weilan[3]brought forward the idea of financial informatization construction on the basis of uncertainty theory, value chain theory and demand theory. Liu Xiaomin[4] studied the main reason by literature survey that hindered accounting informatization and give the solution. Wu Xiaona, Jia Jingquan[5] and Li Ying analyzed the influence factors of rural accounting informationzation management and put forward that government should strengthening the supporting force.

\section{B. Professional Ethics of Rural Accountants}

Wei Tao[6] pointed out the significance of accounting professional ethics construction by analyzing unethical conduct of rural accountants. Liu Zhiqiang[7] considered the president condition of rural accountants professional ethics from appointment standard levels of knowledge and degree of faith three aspects. He analyzed reasons and advanced remedies. Tian Yin[8] expounded the practical significance of improving accounting professional ethics construction. He considered problems existing in rural accounting professional ethics. He Xiaolan[9] did research in current problems existing in rural accountants from the perspective of professional ethics. She gave suggestions combining with the specific circumstances in the countryside. Yang Ming, Li Qingyun and Chen Zhihong[10] discussed the main content of the accounting professional ethics.

\section{Disclosure System of Finance in Rural Areas}

Zhang Zhanhong ${ }^{[1]}$ analyzed the problems existing in the current rural financial disclosure from open time, content, form and supervision aspects, and put forward countermeasures. Pan Ziqiang ${ }^{[12]}$ elaborated the meaning of deepening rural financial disclosure for new rural construction. Yang Shoukang ${ }^{[13]}$ emphasized the causes of current rural financial management problems and put forward some suggestions. Liu Xinyan ${ }^{[14]}$ analyses the problems of China's financial information development, and discusses the development policies about how to develop China's financial information technology, from the rural people's cognitive level, the operation mode of the financial information and the operation of the financial information platform. From the perspective of the rural financial workers, Bo Xiuyun ${ }^{[15]}$ has analyzed the problems of rural accounting team and put forward some improvement measures. 


\section{CHINA'S RURAL ACCOUNTANTS EXISTING PROBLEMS}

China's rural accountant includes cooperative accounting, village accounting and township management accounting. They manage rural property as well as supplies and account daily business transaction. Accountants' work plays an important role in rural economic life. As for the integral level of China's rural accountants, those who have graduate degree take up $0.5 \%$, bachelor degree $12.7 \%$ and college degree $14.2 \%$. The Ministry of Finance chose 149 counties at random in 2014. 147 counties have false assets. The data of inflated assets is 1.848 billion Yuan while reduced assets takes up 2.475 billion Yuan. As to owner's equity, 155 families' data is inaccurate. It made the owner's equity inflate 1.936 billion Yuan virtually. 157 families have unreal profit, which seriously distort the interest. The punishment for rural accountants' irregularities is not strict to staffs but serious to county leaders. This phenomenon encourages evil trends in accountants. Based on these data, we summarize the problems of China's rural accountants as follows:

\section{A. Absence of Professional Knowledge}

The traditional way of rural financial management is no longer applicable along with new rural construction. The quality of China's rural accountants is closely related to the financial management effectiveness. China's rural accountants are lack of professional knowledge. At the same time, the service quality is not high. It mainly displays as follows: Rural economic organizations have multiple bank account and their cash management is chaotic. There are too many types of the bill. Receipt and payment documents are in a mess. In some rural areas, the income and expenditure accounts are not placed on a vital position. They just remember those in the diary of village headmaster, no documents. The result is that there are no accounts available. What's more, they did not keep accounts for five years in some villages. Accountants usually pay without checking or auditing the certificate. Accounting irregularities occurs frequently, and the file management and financial accounting are in disorder.

\section{B. Lack of System Management}

In China's rural areas, spending of violation of accountants is common while the phenomenon of graft and corruption is universal. Accountants usually think that as long as village officer give approval, no matter what all can pay. The actions such as banquet at public expenses and reimbursement are without any institutional restriction. The special investment fund is not used in special fields. Financial disclosure system gets the attention of masses. It has become an essential system to strengthen rural financial management. There are some problems about financial disclosure system in the actual operation. Financial disclosure content is untrue and far from comprehensive. The procedure of disclosure is irregular.

\section{Loss of Professional Ethics}

Different professional personnel in specific activities formed the special professional relationship. We need a system to adapt the characteristics of professional life and adjust the professional norms and social relations.
Professional ethics belongs to the category of public opinion, which can subtly influence people's thinking. Professional ethics is used to guide and restrain professional conduct to ensure normal professional activities. In the countryside, some of the accountants ignore professional ethics cooking the accounts and take advantage of their own career to meet personal desire. The weakening of accounting supervision function in turn prompts more actions contrary to the principle.

\section{Working Enthusiasm Deficiency}

China's rural accountants lack enthusiasm and initiative in work and do not have enough sense of responsibility. Some accountants are selected directly by the village leader team and have multiple-job holding. Their work time is uncertain and decided by their free time and mind. It is negative for rural financial management that they usually discount accounting work.

\section{E. Low Working Efficiency}

With development of informatization, China's financial management also made great progress. But compared with the city, rural areas have a gap. Handicraft account can not meet the demand of huge amount of data which has not adapted to the situation of informatization management system in modern society. It affects the efficiency and specifications of accounting work to a great extent.

\section{CAUSE ANALYSIS OF CHINA'S RURAL ACCOUNTANTS EXISTING PROBLEMS}

\section{A. Reason For Absence of Professional Knowledge}

First, the reason is closely related to the rural accounting environment. The rapid development of economy makes it hard for the rural accounting team install improved in time. The study self-consciousness needs to be improved. Secondly, the rural accountants' appointment is not reasonable. Whether one person is appointed depends on the attitude of the village officer. The appointed accountant is usually from his or her own hometown even dose not have qualification certificate. Finally, there is less income but more debt in countryside where they ignore continuing education.

\section{B. Reason For Lack of System Management}

There are mainly three reasons for the lack of system management. First of all, weak accounting supervision results in it. There is a natural attachment relationship between accountants and main cadres. It is hard for accountants to exercise the power independently. In some places, the auditors do the same work as accountants. They are controlled by local leaders. Secondly, the general farmers do not have enough supervision initiative and become indifferent to rural financial problems. Thirdly, the way of external supervision is not acceptable. There are not any laws about rural cadres' economic problems. It is hard for the judicial office to supervise the cadres. The superior departments in charge pay little attention to the rural financial problems and neglect management.

\section{Reason For Loss of Professional Ethics}

There is a lack of professional accountants in rural areas. Brain drain makes it difficult for countryside to 
bring in high level talents. The hardware facilities have little attraction to the college graduates who do not want to work in countryside. The construction of professional ethics lags behind and can not keep up with the pace of economic development because morality needs a certain amount of time to be accepted and practiced. Village cadres underestimate the importance of accountants' professional ethics training.

\section{Reason For Working Enthusiasm Deficiency}

China's rural accounting team is unstable. The accountants change with the variation of village cadres. Treatment of accountants can not be guaranteed and they usually pay more but return less. The salary of rural accountants is low. Insufficient fund turned over in countryside. Except necessary expenses, there is little surplus to pay for the rural accountants. The salary does not mach the workload. The accounts have unbalanced mentality which influences the enthusiasm to work. Responsibility of accountants is not clear, and there is no division of responsibility. Passing the buck among rural accounts usually happens which affects work efficiency.

\section{E. Reason For Low Working Efficiency}

Financial informatization starts late in China and the ability for countryside to accept new technologies and methods is limited. Talent training is formalistic. As for training content, there is only assessment of computer operation method with little knowledge of accounting informatization software. Many people who have been trained even do not know what the accounting informatization is not to mention how to use soft ware to work efficiently. As to training time, those responsible for training will not take action until the higher investigate progress. Computer technology develops faster and faster. Software updates frequently, so we should update the knowledge system. As for training method, the appropriate authority only pays attention to charge for fee of training. As long as you pay for training, you will have a certificate.

\section{SUGGESTIONS TO SOLVE THE PROBLEMS OF CHINA'S RURAL ACCOUNTANTS}

\section{A. Intensify the Construction of China's Rrural Accountants' Team}

Strengthening the construction of rural financial accounting staff team is an important basis for the standardization of rural financial accounting management. Strictly checking on the enrollment is the first thing for us to do. Allocate more quantity and higher quality accountants and prevent nepotism. All these can make the real talented people come to the position of financial management. Select accountants according to the principles of competition "openness, fairness and justice". Conduct regular assessment of rural accountants to ensure their professional skills meet the requirement of economic development. Implement the preferential policies to guarantee to complete continuing education. The implementation of rural accounting professional management can establish the new personnel system and rural accounting management mechanism which make the outstanding accounting stand out from average people. We can also optimize the structure of rural accounting staff as well.

\section{B. Strengthen the Supervision on China's Rural Accountants' Work}

The government must strengthen the supervision in order to ensure that the rural financial accounting work become more and more regular and institutional. Organize business personnel spot check on the rural financial work situation quarterly. Deal with the problem in time. Encourage villagers to set up the supervision agency. These can form the active awareness to participate in the financial management. Establish the accounting service center to implement accounting accreditation system. Every district need to set up the accounting service center which specialized manage accounting work. Implement accounting accreditation and the accounting personnel appointment are concentrated in the center of the town of accounting services. Township leadership should attach great importance to the financial system in public. Regulate the contents, time, procedure and form of the rural financial disclosure to improve the authenticity of the financial disclosure.

\section{Enhance the Professional Ethics Education of China's Rural Accountants}

The professional ethics of China's rural accountants is the dynamism of high quality financial management. It can make accountants take a correct attitude towards work and set up the lofty ideal. Mobilizing all the forces, the organizations, the masses and the supervision of the media is the key to enhance the construction of professional ethics. Establish the reward and punishment mechanism of rural financial accounting professional ethics. For these accountants in violation of the accounting professional ethics, they should be punished. Encourage the personnel of noble professional ethics. And we can establish and improve the accounting professional ethics education mechanism. Strengthen the main village cadre's moral education.

\section{Establish And Improve the Competitive And Incentive Policy}

Maintain the relative stability of rural financial management team. The employment and treatment of rural accountants should be confirmed in the form of system and economic responsibility. The China's rural accountants should be responsible for their action. Implement the accounting accreditation system and clear the responsibilities of jobs and standards. Every account should know what kind task they have to do and what they can not do. With the development of rural areas and the situation of reform, establishing technology promotion system and scientific accounting personnel assessment methods is necessary. Appropriately increase the wages of rural financial accountants and take efforts to make the same benefits as other cadres. In this way, the rural accountants will have motion to finish their task without worrying about their life.

\section{E. Promote the Development of China's Rural Financial Informatization}

With the continuous improvement of rural economy and society in China, the reform of rural management 
system has been deepened step by step. It has put forward a higher requirement to the management of rural operating management, especially in financial management. At present, most of the rural collective economic organizations lack of informatization workers, they do not even understand the computer. These accountants with low quality are not competent for the financial information work. Therefore, they must be trained in electronic computer operations. Promoting financial informatization, the professional ability and basic quality of specialized people is the linchpin. Train the computer operation for rural financial accountants, and develop the people training program of rural financial informatization. We need to train a group of people who not only understand the computer but also understand the accounting to improve the level of computerized accounting. In this way, we can build a system which is full of efficient facilities and professional accountants. Hardware facilities are the basis to promote financial informatization. All the villages should be equipped with computers, printers, financial software and other facilities to reform the accounting methods.

\section{REFERENCES}

[1] Wang Jian-sheng. Accounting Informatization. 1st ed. Bei Jing: Science Press, 2015.

[2] Liu Zhi-lin. The Impact Factor Analysis of Rural Financial Informatization And Strategic Innovation. Commercial Research, vol. 359, Mar.2007, pp.178-180.
[3] Xu Wei-lan. Innovative Ideas of Rural Financial Informatization Construction. Business Accounting, vol.106,Feb. 2007, pp.80-81.

[4] Liu Xiao-min. Thinking of Rural Accounting Informatization Construction. Business, vol.28, 2015, pp.155.

[5] Wu Xiao-na, Jia Jing-quan, Li Ying. Management Accounting Informatization and Rural Financial Management In Wan Bei. Northern Economy and Trade, Jun.2015, pp.118-119.

[6] Wei Tao. Introduction To The Significance of Strengthening Rural Accounting Pprofessional Ethics. Chinese Agricultural Accounting, Jan.2015, pp.22-23.

[7] Liu Zhi-qiang. Rural Accountants' Professional Ethics Problems. Science \& Technology Vision, vol.23, 2014, pp.344.

[8] Tian Yin. Introduction to Rural Accounting Professional Ethics Construction. Shanxi Agricultural Economy, May.2008, pp.38-40.

[9] He Xiao-lan. Rural Accounting Professional Ethics Construction Problems and Countermeasures Research. Entrepreneur World, Aug.2011, pp.114-115.

Yang Ming, Li Qing-yun, Chen Zhi-hong. Accounting Professional Ethics. 1st ed. Bei Jing: China Finance And Economy Press, 2013.

[10] Zhang Zhan-hong. Introduction to Rural Financial Disclosure And Countermeasures of Public. Farm Staff, Sep. 2011, pp.26.

[11] Pan Zi-qiang. Thinking of Deepening Rural Financial Disclosure In The New Rural Construction. Agricultural Economy, Nov. 2007 pp.70-71.

[12] Yang Shou-kang. Thinking of Strengthening Village-level Financial Management Under the Background of New Rural Construction. Agricultural Economy, Sep. 2012, pp.65-67

[13] Liu Xin-yan. Research On China's Rural Accounting Informatization Development. China's Collective Economy, vol. 36, Dec.2011,pp.8.

[14] Bo Xiu-yun, Research on Weakness and Countermeasures of Rural Accounting Team. Rural Accounting. May.2015, pp56-58. 